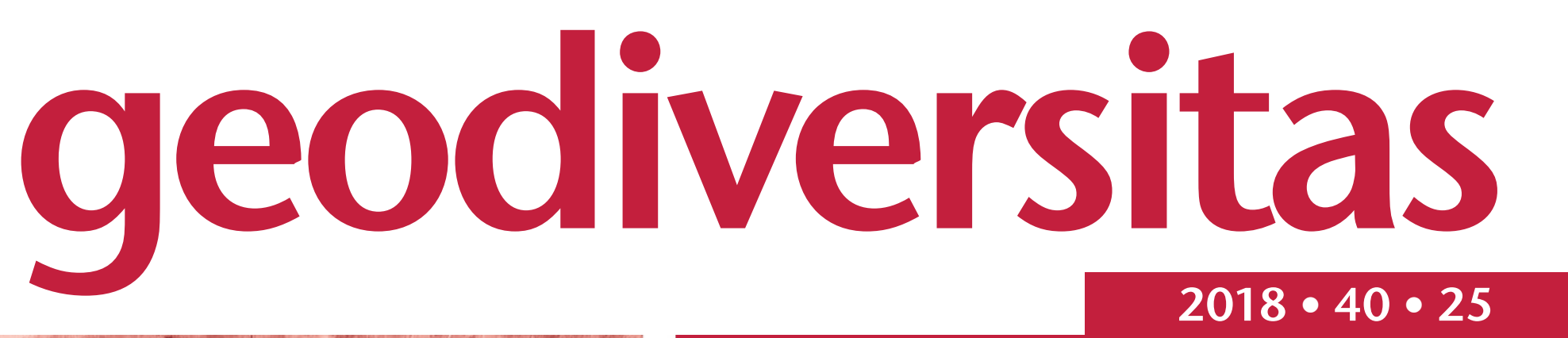

A new partial skeleton of a palaeospinacid shark (Neoselachii, Synechodontiformes) from the Albias: of northern France, with a review of the taxonomic history of Early Cretaceous f. specjes of Synechodus Woodward, 1888

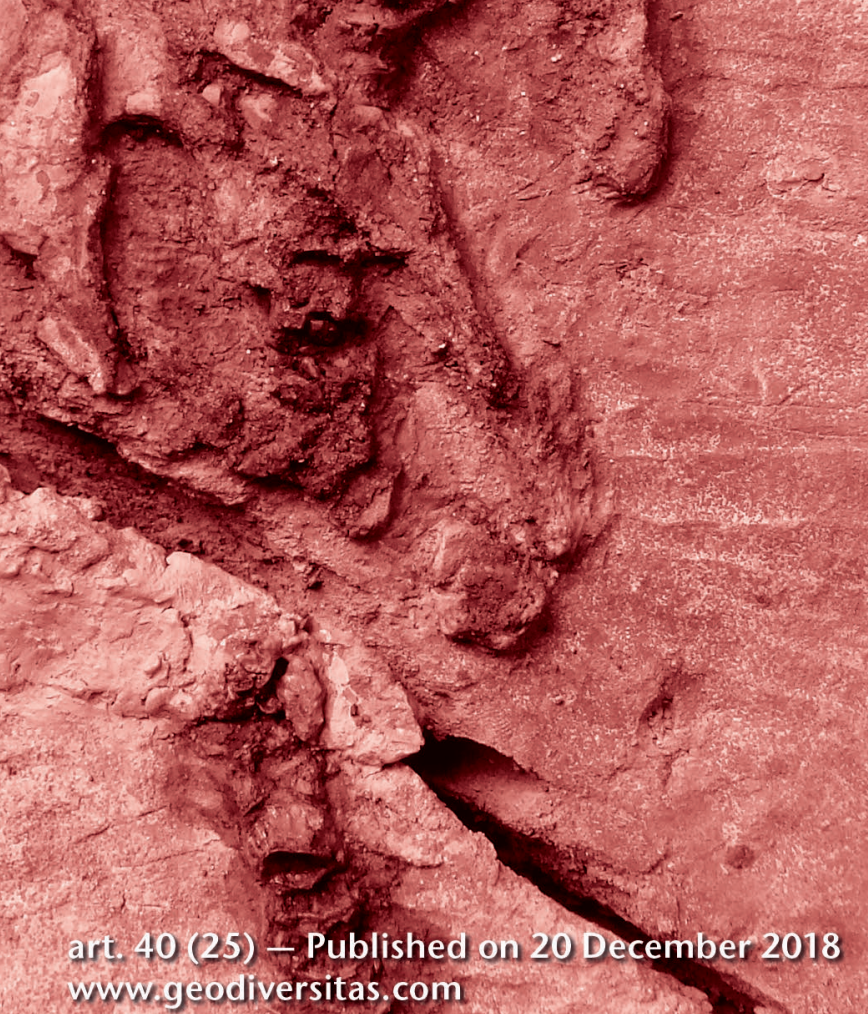

Frederik H. MOLLEN \& Dirk C. HOVESTADT 
DiRECTEUR DE LA PUBLICATION: Bruno David,

Président du Muséum national d'Histoire naturelle

RÉdACTEUR EN CHEF / EDITOR-IN-CHIEF: Didier Merle

ASSISTANTS DE RÉDACTION / AsSISTANT EDITORS: Emmanuel Côtez (geodiv@mnhn.fr); Anne Mabille

MISE EN PAGE / PAGE LAYOUT: Emmanuel Côtez

COMITÉ SCIENTIFIQUE / SCIENTIFIC BOARD:

Christine Argot (MNHN, Paris)

Beatrix Azanza (Museo Nacional de Ciencias Naturales, Madrid)

Raymond L. Bernor (Howard University, Washington DC)

Alain Blieck (USTL, Villeneuve d'Ascq)

Henning Blom (Uppsala University)

Jean Broutin (UPMC, Paris)

Gaël Clément (MNHN, Paris)

Ted Daeschler (Academy of Natural Sciences, Philadelphie)

Bruno David (MNHN, Paris)

Gregory D. Edgecombe (The Natural History Museum, Londres)

Ursula Göhlich (Natural History Museum Vienna)

Jin Meng (American Museum of Natural History, New York)

Brigitte Meyer-Berthaud (CIRAD, Montpellier)

Zhu Min (Chinese Academy of Sciences, Pékin)

Isabelle Rouget (UPMC, Paris)

Sevket Sen (MNHN, Paris)

Stanislav Štamberg (Museum of Eastern Bohemia, Hradec Králové)

Paul Taylor (The Natural History Museum, Londres)

COUVERTURE / COVER:

Partial skeleton of Synechodus sp. (IRScNB P.9895), Saint-Pô Formation (Albian, Lower Cretaceous), Boulonnais beach between Escalles and Strouanne (northern France).

Geodiversitas est indexé dans / Geodiversitas is indexed in:

- Science Citation Index Expanded (SciSearch $\left.{ }^{\circledR}\right)$

- ISI Alerting Services ${ }^{\circledR}$

- Current Contents ${ }^{\circledR} /$ Physical, Chemical, and Earth Sciences ${ }^{\circledR}$

- Scopus ${ }^{\circledR}$

Geodiversitas est distribué en version électronique par / Geodiversitas is distributed electronically by:

- BioOne ${ }^{\circledR}$ (http://www.bioone.org)

Les articles ainsi que les nouveautés nomenclaturales publiés dans Geodiversitas sont référencés par / Articles and nomenclatural novelties published in Geodiversitas are referenced by:

- ZooBank ${ }^{\circledR}$ (http://zoobank.org)

Geodiversitas est une revue en flux continu publiée par les Publications scientifiques du Muséum, Paris Geodiversitas is a fast track journal published by the Museum Science Press, Paris

Les Publications scientifiques du Muséum publient aussi / The Museum Science Press also publish: Adansonia, Zoosystema, Anthropozoologica, European Journal of Taxonomy, Naturae.

Diffusion - Publications scientifiques Muséum national d'Histoire naturelle

CP $41-57$ rue Cuvier F-75231 Paris cedex 05 (France)

Tél. : 33 (0)1 40794805 / Fax: 33 (0)1 40793840

diff.pub@mnhn.fr / http://sciencepress.mnhn.fr

(C) Publications scientifiques du Muséum national d'Histoire naturelle, Paris, 2018

ISSN (imprimé / print): 1280-9659/ ISSN (électronique / electronic): 1638-9395 


\section{A new partial skeleton of a palaeospinacid shark (Neoselachii, Synechodontiformes) from the Albian of northern France, with a review of the taxonomic history of Early Cretaceous species of Synechodus Woodward, 1888}

Frederik H. MOLLEN

Elasmobranch Research, Rehaegenstraat 4, 2820 Bonheiden (Belgium)

frederik.mollen@gmail.com

Dirk C. HOVESTADT

Merwedelaan 6, 4535 ET Terneuzen (The Netherlands)

dmhovest@zeelandnet.nl

Submitted on 9 February 2018 | accepted on 7 September 2018 | published on 20 December 2018

urn:Isid:zoobank.org:pub:3DB706C7-0AE3-4633-8FEB-4F497058FD15

Mollen F. H. \& Hovestadt D. C. 2018. - A new partial skeleton of a palaeospinacid shark (Neoselachii, Synechodontiformes) from the Albian of northern France, with a review of the taxonomic history of Early Cretaceous species of Synechodus Woodward, 1888. Geodiversitas 40 (25): 557-574. https://doi.org/10.5252/geodiversitas2018v40a25. http://geodiversitas.com/40/25

\section{ABSTRACT}

An articulated skeleton of a palaeospinacid shark from the Saint-Pô Formation (Albian, upper Lower Cretaceous) of the Boulonnais (northern France) is described and illustrated for the first time, inclusive of tooth vascularisation and histology. The specimen comprises portions of the neurocanium, splanchnocranium, pectoral girdle, vertebrae, numerous teeth and about 12000 dermal denticles, but no dorsal fin spines. Its dental morphology is unique in combining relatively smooth crown surfaces in anterior teeth, a strongly reticulated ornamentation in latero-posterior teeth and an intermediate ornamentation in larger antero-lateral teeth. The differential diagnoses of three nominal species of Synechodus Woodward, 1888 that have often been recorded from Albian strata (i.e., S. dubrisiensis (Mackie, 1863), S. nitidus Woodward, 1911 and S. tenuis Woodward, 1889) were based mainly on tooth ornamentation. This observation would favour the conspecificity of these three forms, as has been suggested previously by several authors. However, it does not rule out the possibility of more

KEY WORDS

Europe,

Lower Cretaceous,

Palaeospinacidae, skeleton,

vascularisation

comparisons. than one species of Synechodus in the Albian of the Anglo-Paris Basin. Such divergent ornamentation might be characteristic of more than one species, meaning that differentiation would be more complex. Awaiting a thorough revision of these taxa, a review of their taxonomic history is presented here. For the time being, the specimen from the Boulonnais is left in open nomenclature and referred to as Synechodus sp. 
MOTS CLÉS

Europe,

Crétacé inférieur,

Palaeospinacidae, squelette,

vascularisation, comparaisons.

\begin{abstract}
RÉSUMÉ
Description d'un squelette articulé de requin Palaeospinacidae (Neoselachii, Synechodontiformes) provenant de l'Albien du nord de la France, suivi d'une revue taxonomique des espèces du Crétacé inférieur de Synechodus Woodward, 1888.

Un squelette articulé de Palaeospinacidae (Neoselachii, Synechodontiformes) provenant de la formation de Saint-Pô (Albien, Crétacé Inférieur) dans le Boulonnais (Pas-de-Calais, France) est décrit pour la première fois. Le spécimen inclut des éléments du neurocrâne, du splanchnocrâne et de la ceinture scapulaire ainsi que des vertèbres et un nombre élevé de denticules dermiques et de dents orales. La morphologie dentaire du spécimen décrit est toutefois unique, avec des dents antérieures présentant une couronne relativement lisse tandis que les dents des files latérales et postérieures présentent une ornementation parfois très marquée. Étant donné que la diagnose des autres espèces du genre Synechodus Woodward, 1888 couramment retrouvées dans l'Albien (S. dubrisiensis (Mackie, 1863), S. nitidus Woodward, 1911 et $S$. tenuis Woodward, 1889) est essentiellement basée sur l'ornementation dentaire, les caractéristiques de la dentition de ce nouveau specimen suggèrent la probable conspécificité de ces formes, déjà proposée par certains auteurs. Ces résultats n'excluent toutefois pas la possibilité que plusieurs espèces de Synechodus aient coexisté dans l'Albien du bassin Anglo-Parisien. Un tel degré de différenciation dentaire pourrait en effet caractériser plusieurs espèces, ce qui rendrait leur identification plus problématique. En attendant de pouvoir clarifier cette situation, le nouveau specimen est laissé en nomenclature ouverte et il y est référé comme Synechodus sp. Dans ce contexte, la description du squelette est suivie d'une revue taxonomique du genre Synechodus.
\end{abstract}

\section{INTRODUCTION}

The Gault Clay (Albian, upper Lower Cretaceous) of the Boulonnais (northern France) has long been known for yielding elasmobranch remains (see e.g., d'Archiac 1838; Sauvage 1868; Barrois 1874; Leriche 1906; Destombes \& Destombes 1937; Cappetta 1977), but these faunas have not yet been studied in detail. In the present paper, a partially preserved, articulated skeleton of a representative of the genus Synechodus Woodward, 1888 (Synechodontiformes, Palaeospinacidae), about $340 \mathrm{~mm}$ in overall length, is described and illustrated.

The exoskeleton is presented by in situ remains of a relatively well-preserved dentition, as well as several associated isolated teeth and about 12000 dermal denticles that were recovered by wet sieving and processing the clayey matrix that was left following preparation of the skeletal remains. The endoskeletal elements preserved include parts of the neurocranium, splanchnocranium, pectoral girdle and vertebral column. All elements are illustrated and described below, with the emphasis on teeth and dermal denticles. Prior to final burial, the endoskeleton had partially decomposed and elements had become displaced.

Representatives of the genus Synechodus have been recorded for over a century from the Gault Clay in southern England (see Woodward 1888: 499), but were unknown from northern France until Herman's (1977: 29, footnote) record. Later, Cappetta $(1987,2012)$ recorded the genus from Wissant, which is quite near the locality from where the present skeleton was collected. Herman $(1977)$ and Cappetta $(1987,2012)$ referred their Synechodus material to S. dubrisiensis (Mackie, 1863) and S. nitidus Woodward, 1911, respectively.

Both species were originally described from the English Chalk (Cenomanian, Upper Cretaceous), on the basis of exceptionally well-preserved associated pairs of jaws, includ- ing several teeth in more or less natural position. Despite the quality of the type material of both species and the availability of numerous additional specimens that had traditionally been assigned to $S$. dubrisiensis, specific differentiation between these two, and even a third species, S. tenuis Woodward, 1889, has proved difficult and controversial to date. Below, we discuss their taxonomic history in order to assess to which of these the newly collected 'Boulonnais specimen' should be assigned.

\section{MATERIAL AND METHODS}

\section{REPOSITORY}

The present specimen (referred to below as 'the Boulonnais specimen') consists of a partially preserved, articulated skeleton, eight isolated teeth, four clusters of dermal denticles (two of them have denticles preserved in situ) and about 12000 isolated dermal denticles. All material is deposited at the Institut royal des Sciences naturelles de Belgique (Brussels), and is registered under a single collection number, IRScNB P.9895.

\section{GEOGRAPHICAL AND GEOLOGICAL SETTING}

The 'Boulonnais specimen' originates from a clay level that was exposed on the beach between Petit Blanc-Nez and Strouanne, about $15 \mathrm{~km}$ southwest of Calais (see Fig. 1). Stratigraphically, this specific bed of the Saint-Pô Formation (middle Albian) was situated between phosphatic levels P4 and P5 (see Fig. 2). It was discovered by chance on May 18, 1996 (collector: Luc De Coninck); a few associated vertebrae, washed free by tidal currents suggested that possibly more elements of a skeleton could be matrix embedded. For more detailed stratigraphical information, reference is made to Robaszynski \& Amédro (1986) and Amédro (2009). 


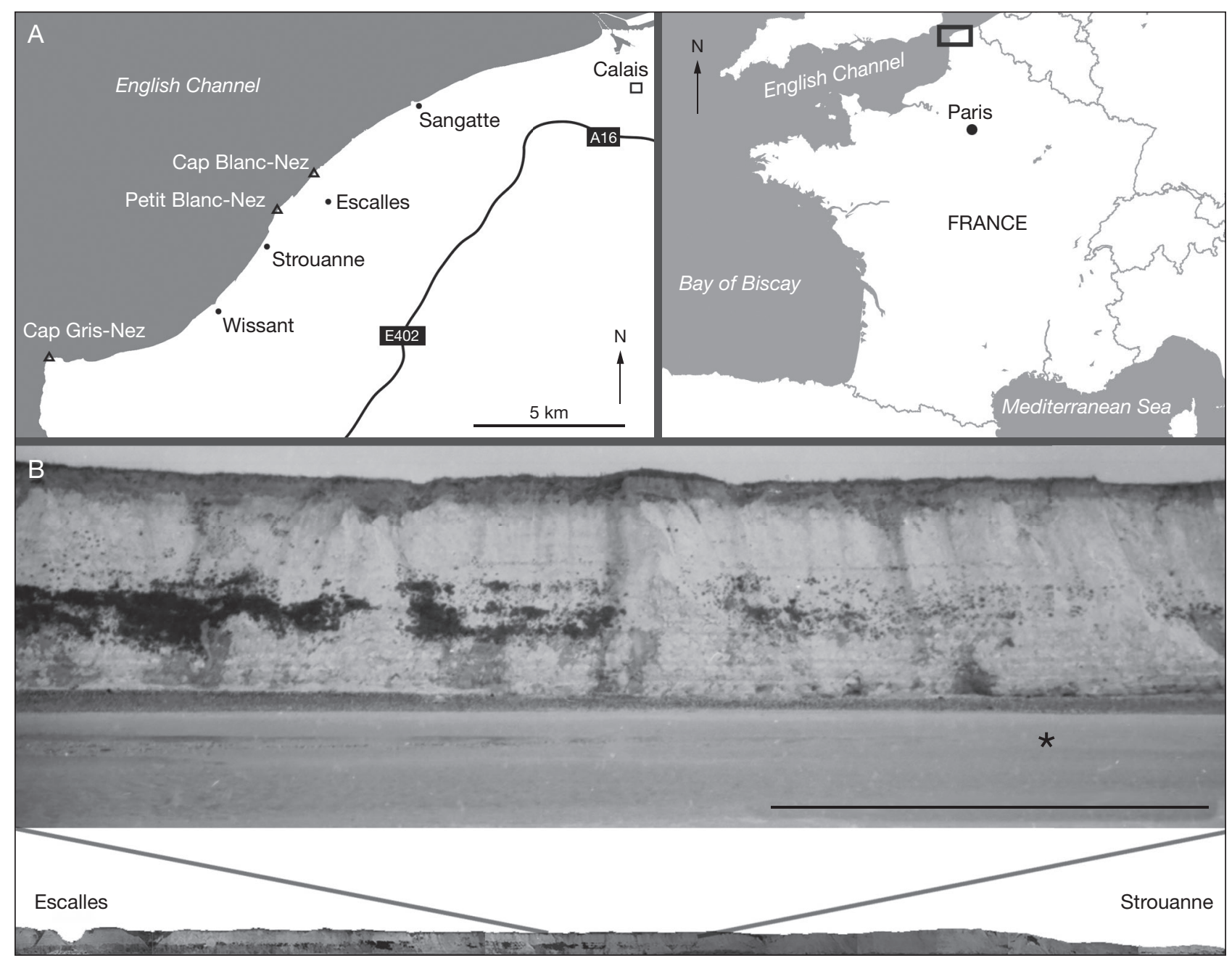

FIG. 1. - Geographical map (A) and Boulonnais beach (B, situation in 1990) between Escalles and Strouanne (northern France); the skeleton of Synechodus sp. (IRScNB P.9895) was collected in 1996 from the clay level exposed at the beach, as indicated by the asterisk (*). Scale bar: B, $500 \mathrm{~m}$.

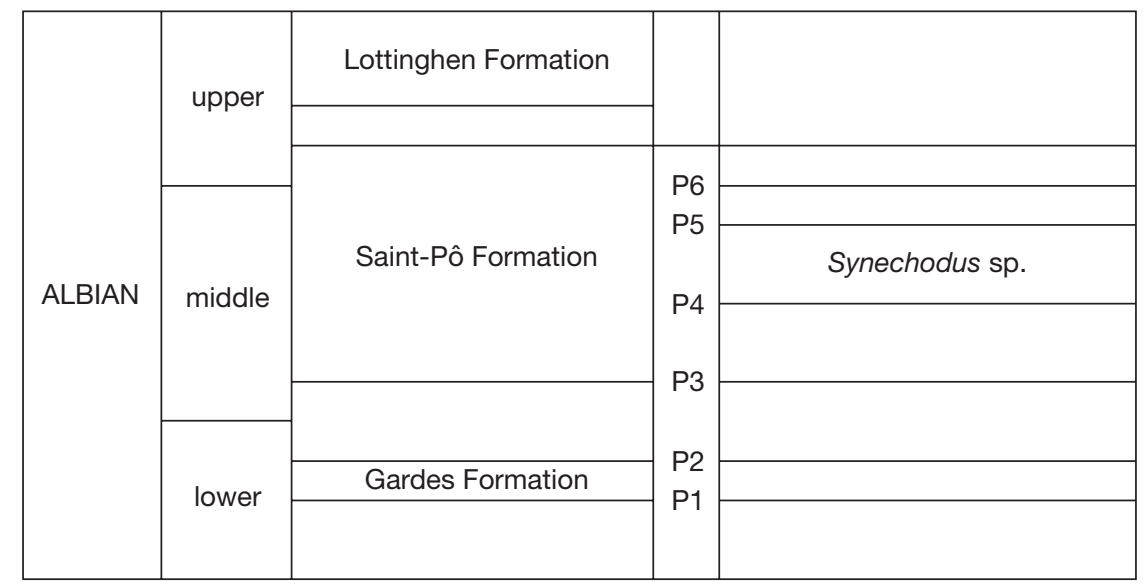

FIG. 2. - Stratigraphy of the Saint-Pô Formation (middle Albian, Lower Cretaceous) as exposed on the Boulonnais beach between Escalles and Strouanne, northern France (after Robaszynski \& Amédro 1986; Amédro 2009); the specimen of Synechodus sp. (IRScNB P.9895) was recovered from between phosphatic horizons $\mathrm{P} 4$ and P5.

SALVAGING, PREPARATION AND CONSERVATION

A large block of clay was cut out around the vertebrae, which broke into two pieces while removing it from the beach. Both pieces were skillfully salvaged and X-rayed prior to preparation; images revealed a vague silhouette of several parts of the specimen. Subsequently, preparation consisted of scraping away the 
surrounding clayey matrix, whilst keeping the blocks wet by moist cloths. This method revealed large portions of a partially decomposed skeleton, comprising roughly one third of the ventral part of the body with the dorsal part embedded in the clay (for details, see Description below). The excess clay was dried and then soaked in water, breaking up the clay into a slush that was wet sieved over a $0.2-\mathrm{mm}$-mesh. The dried residue was then checked for material under a binocular; this yielded several teeth, fragments of teeth and many thousands of dermal denticles.

Following preparation, the blocks were put in a plastic bag, leaving a small opening so that moist air might be replaced by dry air. This technique allowed the pieces to dry very slowly and avoided cracking of the clay during the process. Finally, both blocks were treated with thermoplastic resin (Paraloid B72) for future preservation, although this resulted in a shiny appearance of the specimen. During preparation of the present paper, the resin layer was removed to optimise photographic results. This yielded better-quality pictures; an earlier attempt to photograph the specimen in different focal planes and with ammonium chloride coating (courtesy of B. W. M. van Bakel), had proved unsuccessful.

\section{COMPUTED TOMOGRAPHY AND IMAGING}

The smallest of the two blocks was CT scanned at the Institut royal des Sciences naturelles de Belgique (courtesy of U. Lefevre) using an RX Solutions EASYTOM 150, with tube power of $40 \mathrm{~W}$, voltage of $112 \mathrm{kv}$ and current of $354 \mu \mathrm{A}$. A scanning time of three hours and 40 minutes resulted in a data set of 1440 RX images and 2190 slices, but contrast between the clay and fossil could not be detected, which precluded visualisation of matrix-hidden portions of the skeleton. In view of the negative result of this preliminary scan, no further attemps were made.

In order to examine tooth vascularisation and histology, an isolated tooth was $\mu$ CT scanned at the Centre of GeoEnvironmental Research and Modelling (GEOMODEL) at St Petersburg State University (courtesy of A. O. Ivanov and $\mathrm{S}$. Nilov). Inner structures were visualised using a Bruker SkyScan 1172 , at $100 \mathrm{kV}$ and $100 \mu \mathrm{A}$, with an aluminium filter and average rotation step of $0.2^{\circ}$. InstaRecon, DataViewer, CTAn and CTVox software were used in creating $3 \mathrm{D}$ volume renderings of the tooth.

\section{ABBREVIATIONS}

\section{Institutional abbreviations}

Material discussed in the present study is housed in the following collections:

BMB Booth Museum of Natural History, Brighton;

IRScNB Institut royal des Sciences naturelles de Belgique, Brussels;

NHMUK The Natural History Museum, Department of Palaeontology, London.

$\begin{array}{ll}\text { Anatomical abbreviations } \\ \text { EN } & \text { enameloid; } \\ \text { PC } & \text { pulp cavity; } \\ \text { ORD } & \text { orthodentine; } \\ \text { OSD } & \text { osteodentine; } \\ \text { SC } & \text { secondary cavities; } \\ \text { VC } & \text { vascular canaliculi. }\end{array}$

\section{SYSTEMATIC DESCRIPTION}

Systematics follow Cappetta (2012).

Class CHONDRICHTHYES Huxley, 1880

Subclass ELASMOBRANCHII Bonaparte, 1838

Neocohort NEOSELACHII Compagno, 1977

Order SYNECHODONTIFORMES Duffin \& Ward, 1993

Family PALAEOSPINACIDAE Regan, 1906

Genus Synechodus Woodward, 1888

TYPE SPECIES. - Hybodus dubrisiensis Mackie, 1863, by original designation.

\section{Synechodus sp.}

(Figs 3-7)

\section{DESCRIPTION \\ General outline}

Skeletal remains of about $340 \mathrm{~mm}$ in overall length are preserved in two associated blocks of Gault Clay (Fig. 3), the smallest one of which comprises a series of (precaudal) vertebrae only, whereas the larger block contains the major part of the skeleton. The latter reveals several skeletal elements (i.e., parts of the neurocranium, splanchnocranium, pectoral girdle, vertebral column, teeth and dermal denticles), most of which are displaced as a result of partial decomposition prior to final burial. Dorsal fin spines have not been found. The ventral side of the specimen is exposed, slightly tilted to the right and certain skeletal elements twisted with the pectoral girdle overlying the vertebral column. Consequently, the right side of the individual can be observed on the left side of the blocks and vice versa.

\section{Endoskeleton}

Neurocranium (Fig. 3A, B, in red colour). Poorly preserved; it consists of indeterminate cartilage remains (about $47 \mathrm{~mm}$ in length) that are in part separated from all other skeletal elements, suggesting that these had become detached and moved anteriorly from the remainder of the skeleton. Normally, in ventral view, the posterior part of the neurocranium would have been overlain by the anterior half of the splanchnocranium.

Splanchnocranium (Fig. 3A, B, in orange colour). Well preserved, albeit in part only. Its right side displays three abutting and partially overlapping cartilage structures that are semi-parallel. The uppermost and median structures cover the median and lowermost ones, respectively. As a result, the latter two are only partially exposed and are presented as long and slender cartilaginous structures. The uppermost structure is significantly wider. An identical broad cartilaginous structure is present on the other (left) side of the splanchnocranium.

A set of associated teeth is seen near the anteriormost edge of the lowermost cartilaginous structure; these have slightly shifted from their original position (see Figs 3A, 


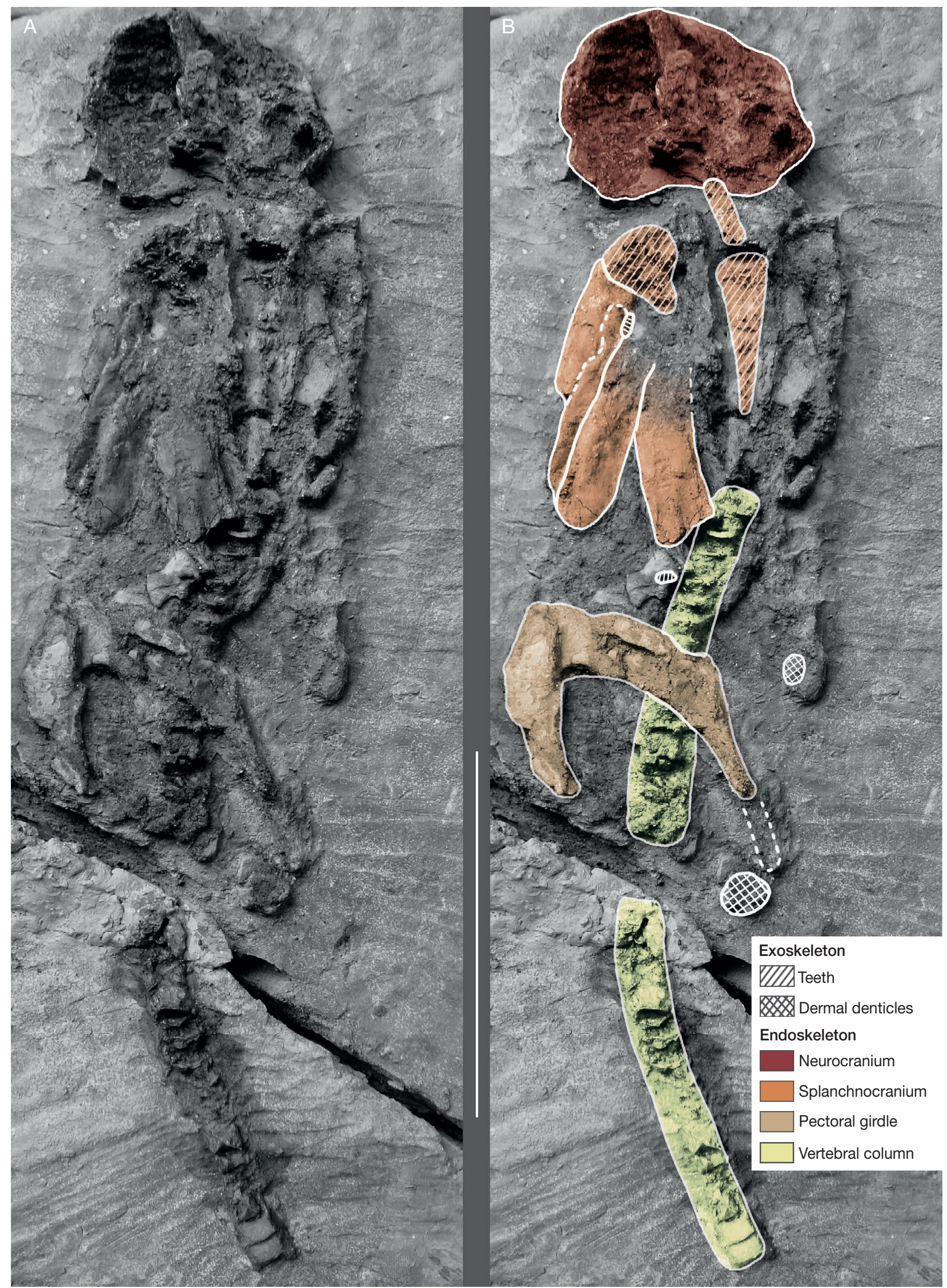

FIG. 3. - A, Partial skeleton of Synechodus sp. (IRScNB P.9895), Saint-Pô Formation (Albian, Lower Cretaceous), Boulonnais beach between Escalles and Strouanne (northern France); B, Same specimen with interpretation of the exoskeleton (hatching) and the endoskeleton, including parts of the neurocranium (red), splanchnocranium (orange), pelvic girdle (beige) and vertebrate column (yellow). Scale bar: $100 \mathrm{~mm}$. 
B; 4A).This lowermost structure is considered to represent a major portion of the right upper jaws (palatoquadrate). Another set of associated teeth is present on the left side of the mandibular arch (present on the right side of the block; Fig. 4B). This set comprises a series of latero-posterior teeth, exposed mainly by the basal face of their roots and representing several different tooth files, all preserved in situ. The uppermost cartilaginous structure, which is rather massive and wide in comparison to the other two, is tentatively interpreted as the right part of the lower jaws (Meckel's cartilage) and the opposite one on the right side of the block as the left part of the lower jaws. The median cartilaginous structure, as well as other cartilaginous fragments in this skeletal region, remain indeterminate because of poor preservation (see Discussion below).

Pectoral girdle (Fig. 3A, B, in beige colour). Although slightly twisted, it is relatively well preserved and in its original position, i.e., posterior to the splanchnocranium and a series of at least five (preserved) vertebrae. It comprises the coracoid bar and both scapulae, of which the left one appears to possess the remains of the suprascapular (Fig. 3A, B, in dotted line), i.e., just anterior to a cluster of dermal denticles.

Vertebral column (Fig. 3A, B, in yellow colour). It is represented by more than ten monospondylous precaudal vertebrae, along with several impressions of other vertebrae. One vertebra is particularly well preserved; this sits in the smaller of the matrix blocks (Fig. 4E).

\section{Exoskeleton}

Dorsal fin spines. Dorsal fin spines have not been found, although neither traditional X-ray analysis nor CT scanning could rule out their presence in the matrix.

Dermal denticles or placoid scales. A large number of dermal denticles are present, some in their original positions of shagreen patches (see Figs 3A, B; 4C, D). Three morphotypes can be distinguished.

The majority of denticles (Fig. 5A-D) possess a median keel, formed by two diverging ridges, with a broad and slightly rounded anterior margin, ending in a sharp posterior apex that has a slightly concave crown surface. On both sides of the median keel, a lateral ridge is present. The surface between the median keel and both lateral ridges is concave; the same goes for the surface between the ridges and lateral margins of the denticle. The anterior margin of the denticle is concave and curved between the median keel and the ridges in occlusal view, whereas the posterior margin shows two to three apices on both sides of the median keel.

The second morphotype (Fig. 5E-G) is oval shaped in occlusal view, has a flat crown surface and lacks a keel and lateral ridges. One or two costules are present at the anterior margin, in contrast to several shallow depressions at the posterior margin that may be a relic of apices. In this morphotype, dermal denticles occasionally are fused.
The third type (Fig. 5H) has a flat crown surface, a more or less rounded anterior margin with mesial and distal depressions and approximately nine to ten short ridges at the rear end.

However, several dermal denticles are of a shape that is intermediate between those described above.

Teeth. Morphological descriptions are based on seven isolated teeth (Fig. 6A-G), representing anterior, anterio-lateral, lateral, latero-posterior and posterior jaw files. Teeth embedded in the clay are exposed only in part and are not considered in the description below.

First tooth (Fig. 6A). The width and height of the first tooth, from an anterior file, are equal. It possesses a tall, elongated, upright and inwardly directed principal cusp, the height of which is twice the basal width. The principal cusp is also slightly curved distally and twisted along its axis. In labial view, a bulge is present at the crown base. The mesial cutting edge is smooth and slightly convex, while the distal one is slightly concave. Three distal cusplets are present, probably forming pairs with the mesial ones, but only the proximal one is preserved. The height of the first distal cusplet is one seventh of the principal cusp, the second one half the height of the first one and the third one third of the second one. A minute intermediate cusplet, of a size equal to the third cusplet, is present at the distal cutting edge between the principal cusp and the first proximal cusplet. The labial surface of the crown is smooth, with minute reticulations along the base only and some insignificant vertical ridges, one on each cusplet. The lingual surface is smooth along the base but presents an undulating ridge from which folds extend up to two-thirds of crown height. The lingual part of the root is rounded with several minute foramina present along the lingual margin of the root and two or three larger ones between lingual root margin and crown base. The labial part presents five parallel indentations that are more or less equally distributed along the crown width. Although barely visible due to sediment cover, a central foramen is present in the depression between two indentations.

Second tooth (Fig. 6B). From an antero-lateral file, it is twice as wide as tall and possesses a slightly distally oblique principal cusp, with five mesial and four distal cusplets. Both cutting edges are smooth and concave. The first mesial and distal cusplets are one fifth the height of the principal cusp; successive cusps become gradually lower towards the distal margin of the crown. In labial view, a bulge is present at the crown base. The lingual surface presents minute folds that extend from one fifth the height of the crown reaching to two fifths of the crown base. The labial surface of the crown shows minute semi-vertical ridges at the crown base of the first mesial and distal cusplet which become higher and merge, reaching the apex of the cusplet. The lingual part of the root is slightly rounded with several minute foramina present along the lingual margin of the root and two to three larger ones in shallow depressions at the surface between lingual root margin and crown base. The labial part presents four equalsized parallel indentations and, although barely visible due to sediment cover, a central foramen is present in the indentations. 


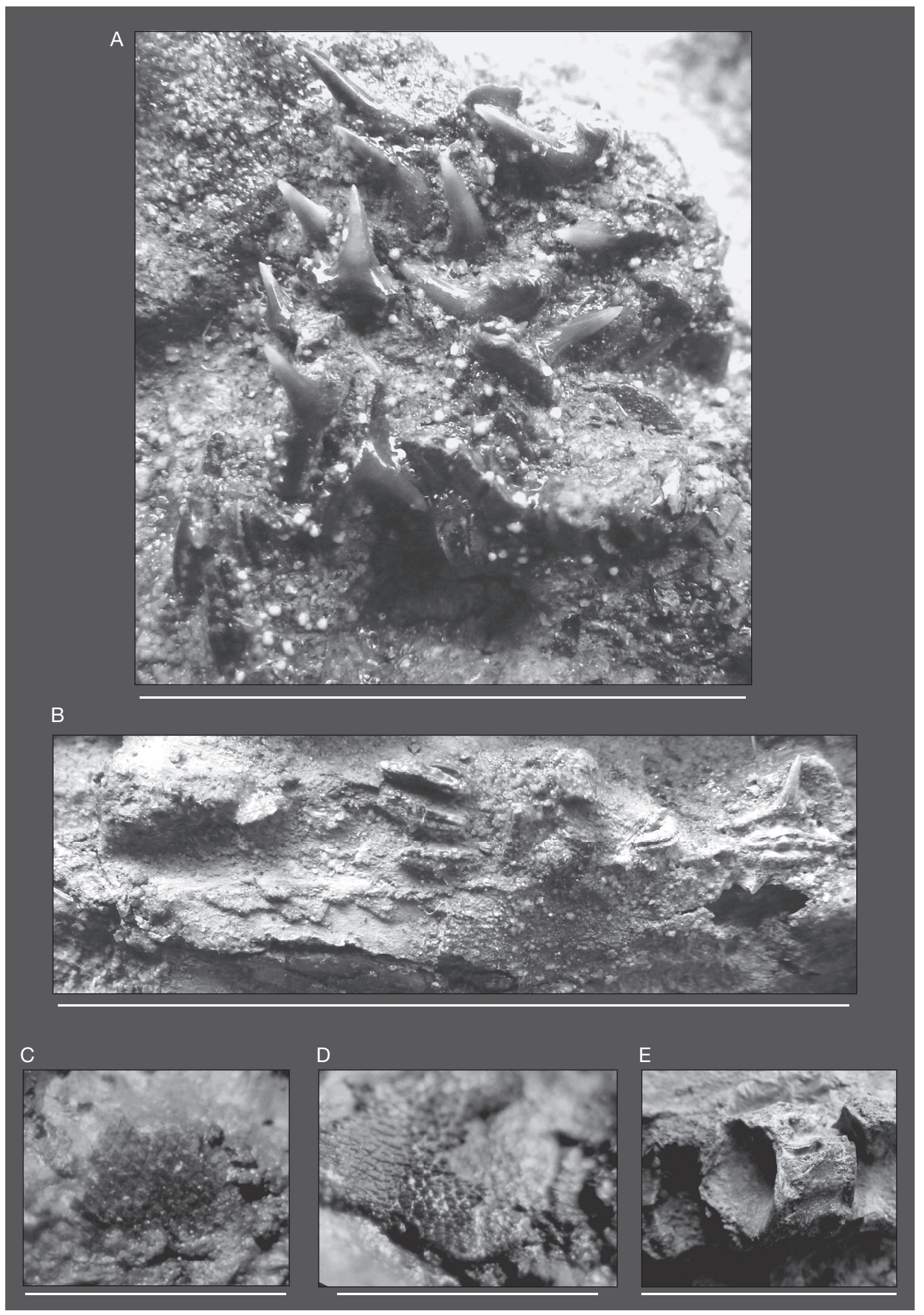

FIG. 4. - Selected details (in situ) of a partial skeleton of Synechodus sp. (IRScNB P.9895), Saint-Pô Formation (Albian, Lower Cretaceous), Boulonnais beach between Escalles and Strouanne (northern France): A, cluster of anterior teeth; B, cluster of lateral teeth; C, D, patches of dermal denticles; E, precaudal monospondylous vertebrate. Scale bars: A, $250 \mathrm{~mm}$; B, $300 \mathrm{~mm}$; C-E, $150 \mathrm{~mm}$. 
Third tooth (Fig. 6C). From a lateral file, it is three times wider than tall. The tooth possesses a slightly distally oblique principal cusp, with four mesial and three distal cusplets. Both cutting edges are smooth and concave. The first mesial and distal cusplets are one third the height of the principal cusp, the following cusps gradually become lower towards the crown margins. The apex of the cusplets is slightly worn. In labial view, a bulge is present at the crown base. The labial surface of the crown has tiny folds extending from the crown base reaching to a longitudinal ridge situated just above the crown base, forming a reticulated pattern. Two to three, more or less vertical, folds extend from the ridge towards the apex of the principal cusp. The lingual surface of the crown shows a shallow depression (i.e., neck or collar) along the crown base with an irregularly shaped, more or less undulated upper margin forming a longitudinal ridge. From this ridge seven to eight, well-developed, semi-vertical folds mostly extend to halfway the apex of the crown. The lingual part of the root is slightly rounded with several minute foramina present along the lingual margin of the root and seven to eight larger ones in shallow depressions at the surface between lingual root margin and crown base. The labial part presents seven, poorly preserved, parallel indentations that are more or less equally distributed over the crown width. Although barely visible due to sediment cover, a central foramen is present in the depression between two indentations.

Fourth tooth (Fig. 6D). It is from a lateral file and five times wider than tall. The incomplete tooth lacks a small part of the mesial end. The crown possesses an upright principal cusp with four low and poorly developed distal and probably three low and poorly developed mesial cusplets. Both cutting edges are smooth and concave. In addition to the lower principal cusp and the lesser-developed cusplets, the tooth shows the same characteristic features as the second one. In labial view, a bulge is present at the crown base.

Fifth tooth (Fig. 6E). It is from a very lateral file, close to the posterior files. The principal cusp and cusplets are replaced by an irregularly shaped longitudinal ridge. The lingual surface of the crown has tiny folds extending from the crown base and reaching a longitudinal ridge situated just above the crown base. The labial surface of the crown shows a shallow depression along the crown base with an irregularly shaped, more or less undulated upper margin, forming a longitudinal ridge. The lingual part of the root is slightly rounded at the mesial and distal margins with several more or less scattered foramina along the basal margin of the root. The labial part presents seven to eight, poorly preserved parallel indentations that are more or less equally distributed over the crown width, with a central foramen present in the depression between two indentations.

Sixth tooth (Fig. 6F). It is from a very lateral file as well, close to the fifth one, and approximately four times wider than tall. The principal cusp and cusplets are replaced by an irregularly shaped longitudinal ridge of which some remains of cusp or cusplets can be recognised. Both lingual and labial surfaces of the crown have characteristics that are similar to those of the fifth one. Both lingual and labial parts of the root are covered with sediment which precludes further examination.

Seventh tooth (Fig. 6G). It is from a posterior file. The crown is similar to the lateral ones described above, having the same characteristics. The tooth is less wide than the lateral ones and three times wider than tall.

\section{Tooth vascularisation and histology}

The root of all teeth is wide, pseudopolyaulacorhizid (sensu Cappetta 1987, 2012), and has a flat base. In order to document the inner vascularisation, another tooth, from a lateral file, was $\mu \mathrm{CT}$ scanned (Fig. 7A-E). Histologically, three layers are visible, i.e., osteodentine (OSD), orthodentine (ORD) and enameloid (EN). The orthodont tooth possesses a large, mesiodistally wide pulp cavity (PC; Fig. 7A2, A3). A series of smaller secondary cavities (SC) are present in the osteodentine at the labial part of the root; these are part of the walls of the indentations of the root (Fig. 7A3, C2). A relatively thick structure of dense dentine separates these walls from each other and from the finer osteodentine of the lingual part (Fig. 7C2). A vertical bundle of vascular canaliculi (VC) connects the osteodentine layer with the principal crown (Fig. 7A2). A series of similar, semi-vertical vascular canaliculi extend from the osteodentine layer towards the crown section. Both series of relatively large labial and lingual foramina are connected to separate secondary cavities (SC) of the osteodentine, but not to the pulp cavity (Fig. 7A3, C1).

\section{DISCUSSION}

\section{ENDOSKELETON}

Description and identification of most skeletal elements has proven challenging, because many had partially decomposed and displaced prior to final burial and lack diagnostic features.

In particular, this is the case for the neuro- and splanchnocranium. When complete, the latter includes the mandibular, hyoid and branchial arches. In Synechodus, skeletal elements of the branchial arches (e.g. cerathobranchials and epibranchials) are extremely long and slender (see Maisey 1985: 15); such skeletal elements do not appear to be preserved in the present specimen. In contrast, three robust, abutting cartilaginous structures are preserved in the right half of the splanchnocranium (see Description). In our opinion, the size of the posterior/uppermost cartilaginous structure is too large to represent the ceratohyal (i.e., the ventral portion of the hyoid arch). Rather, the posterior/ uppermost and anterior/lowermost cartilaginous structures are here considered to represent portions of Meckel's cartilage and palatoquadrate, respectively. As a result, both lower and upper jaws (mandibular arch) are not articulated, nor do they abut, but are separated by another cartilagi- 


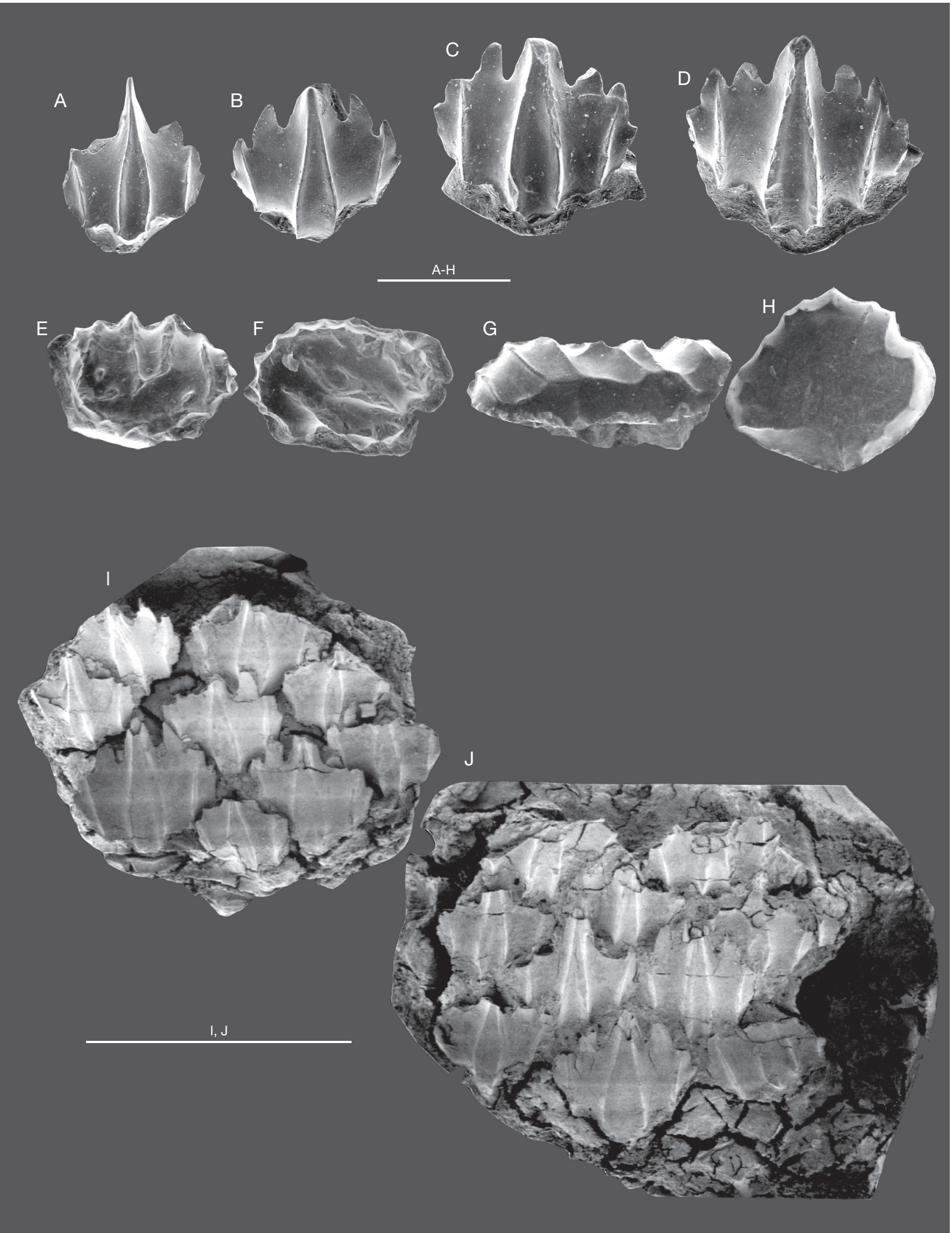

FIG. 5. - Associated set of isolated dermal denticles of Synechodus sp. (IRScNB P.9895), Saint-Pô Formation (Albian, Lower Cretaceous), Boulonnais beach between Escalles and Strouanne (northern France): from presumed trunk (A-D), fin (E-G) and snout (H) areas, or preserved as cluster (I, J). Scale bars: A-H, $0.5 \mathrm{~mm}$; I, J, $1 \mathrm{~mm}$. 
nous stucture. Perhaps the mandibular arch was fractured longitudinally (Fig. 3B, in dotted line), but in view of the general morphology of the splanchnocranium, it cannot be ruled out either that elements of the hyoid arch could have moved in between, as Meckel's cartilage had shifted from its original position and is flattened.

In contrast to the neuro- and splanchnocranium (axial skeleton), the pectoral girdle (anterior appendicular skeleton) is better preserved. Its median portion, or coracoid bar, appear to be more or less rectilinear, in contrast to the pectoral girdle of $S$. dubrisiensis as illustrated by Woodward (1911: pl. 46, fig. 2), which is much more arched. However, in the 'Boulonnais specimen', the girdle has become slightly twisted, thereby losing its original, symmetrical shape (see Description), making it difficult to situate its medial joint exactly or checking the presence of a sternal cartilage. This explains the differences observed, at least in part, and precludes any firm conclusions.

In consideration of the estimated total number of 110 140 vertebrae in synechodontiform sharks (see Dean 1909; Klug \& Kriwet 2006), only a small (anterior) portion of the vertebral column is preserved in the present specimen. This does not include the monospondylous-diplospondylous transition (in general allocated near the pelvic region), but shows only well-calcified monospondylous precaudal vertebrae. The best-preserved vertebra (see Fig. 4E) measures 7 $\mathrm{mm}$ in length and $8.6 \mathrm{~mm}$ in width, showing rudimental depressions for neural and/or hemal arches. Vertebrate typology (sensu Hasse 1879) in S. dubrisiensis was interpreted as 'asterospondylic' (Woodward 1888, 1898, 1911; Klug \& Kriwet 2006), but CT scanning did not yield images of inner structures to verify this for the 'Boulonnais specimen'.

Based on all endoskeletal elements preserved (i.e., neurocranium, splanchnocranium, pectoral girdle and vertebrae), the total body length of the present individual is estimated to have been approximately $700 \mathrm{~mm}$. Cartilage preservation is rather poor, which is why the specimen cannot supply more data on the skeletal morphology of Cretaceous Synechodus. However, the exoskeleton does provides more detailed information, as shown below.

\section{EXOSKELETON}

\section{Dorsal fin spines}

Both Synechodus and Palidiplospinax Klug \& Kriwet, 2008 have two dorsal fins, but dorsal fin spines have only been demonstrated for the latter taxon to date. Klug (2010: 45) suggested that these had been secondary lost in Synechodus, but this was subject to debate because of the partial preservation of the material (see Cappetta 2012). The 'Boulonnais specimen' apparently lacks dorsal fin spines; due to poor CT scanning results, the inner matrix could not be examined so that this matter (presence or absence of dorsal fin spines in Albian Synechodus) cannot be resolved.

\section{Dermal denticles or placoid scales}

In selachians, dermal denticle morphology varies significantly depending on their position on the body. Based on recurring patterns of variation seen in fossil and Recent sharks (see e.g. Reif 1973: 5; 1985), we assume that morphotypes one, two and three as observed in the "Boulonnais specimen' (see Description), originate from the trunk, fin and snout regions, respectively. The assignment of the first morphotype to the trunk also clarifies their abundance.

All four patches of shagreen exhibit a pattern of narrowly spaced dermal scales. Two isolated patches (Fig. 5I, J) belong to the first (i.e., trunk) morphotype, whereas two other patches that have preserved in situ (Figs 3B; 4C, D), positioned near the pectoral girdle, belong to the second (i.e., fin) morphotype.

\section{Teeth}

Albian strata of the Anglo-Paris Basin have yielded different tooth types of Synechodus. In the past, these have been referred to different taxa, including $S$. dubrisiensis, S. nitidus and S. tenuis (see e.g., Biddle 1993; Underwood \& Mitchell 1999; Cappetta 2010); the differential diagnoses of which were based mainly on tooth ornamentation. However, several associated tooth sets from the English Chalk (as well as bulk samples from other localities, including other Cretaceous strata) have indicated intraspecific variation with, at least, monognathic and dignathic heterodonty and possible ontogenetic changes as well as sexual dimorphism, that explain the presence of several morphotypes. Subsequently, the validity of $S$. tenuis and $S$. nitidus has been questioned by several authors. Soon after $S$. nitidus had been considered to be a junior synonym of $S$. tenuis (see Batchelor \& Ward 1990), S. dubrisiensis was claimed to be a senior synonym for both $S$. tenuis and $S$. nitidus, and thus finally only a single species remained, according to Ward (2010). However, certain variations in dental morphology of (Albian) species of Synechodus remain problematic to date and are not fully understood. Some of these variations might still reflect interspecific, rather than intraspecific, differences. A review of their taxonomic history is presented in Appendix 1.

Dalinkevičius (1935) was the first to be confronted with species separation in Cretaceous Synechodus as defined by Woodward (1911). In his collection of more than 100 complete teeth of Synechodus, originating from both upper Albian and upper Cenomanian strata (for stratigraphical interpretation, see Adnet et al. 2008), Dalinkevičius noted that he was unable to distinguish $S$. nitidus from S. dubrisiensis. Although most of his teeth resembled those of $S$. nitidus, some were much closer to $S$. dubrisiensis, whilst others shared diagnostic characters that were used by Woodward to separate both species. However, this did not prevent Dalinkevičius from listing all material as $S$. nitidus.

Despite the problem that Dalinkevičius (1935) faced, the definition or validity of certain species of Synechodus known so far to occur in the Albian, has never been questioned until Batchelor \& Ward's (1990) paper on fish remains from Aptian strata exposed near Godstone, Surrey (England). Next to about 30 specimens of $S$. dubrisiensis, they also recorded 


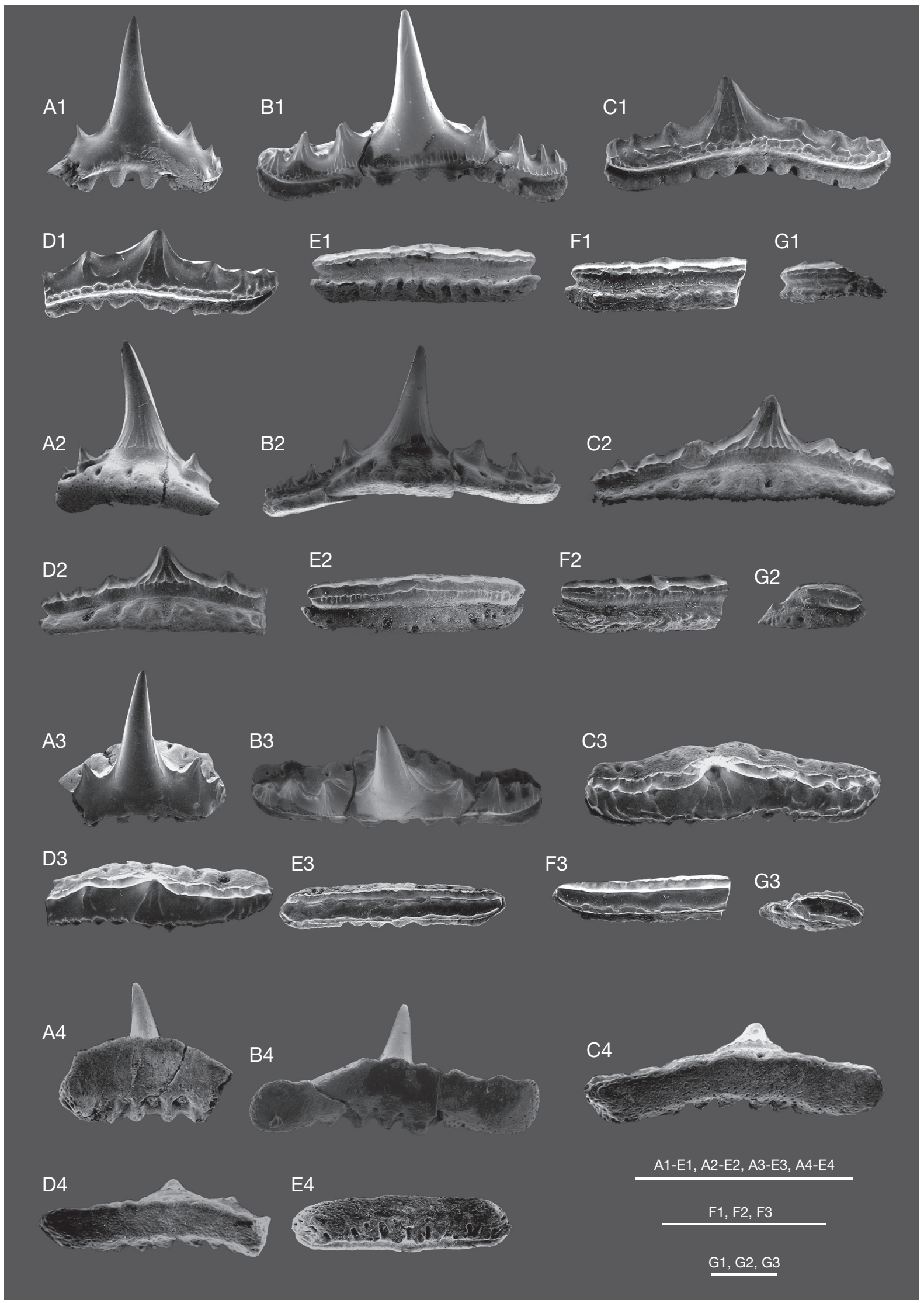

FIG. 6. - Associated set of isolated teeth of Synechodus sp. (IRScNB P.9895), Saint-Pô Formation (Albian, Lower Cretaceous), Boulonnais beach between Escalles and Strouanne (northern France): A, anterior; B, antero-lateral; C, D, lateral; E, F, latero-posterior and G, posterior tooth files, in labial (1), lingual (2), occlusal (3) and basal (4) views. Scale bars: A-E, $5 \mathrm{~mm} ; \mathrm{F}, 4 \mathrm{~mm} ; \mathrm{G}, 2 \mathrm{~mm}$. 
a single tooth of $S$. tenuis. In their discussion, they suggested $S$. tenuis to be a senior synonym of $S$. nitidus. Except for the fact that both species are very similar, with the former described on limited type material in poor condition, they did not outline this hypothesis in any detail. Although they preferred to postpone their conclusions until more and better-preserved material would become available, their hypothesis received much attention (e.g., Biddle 1993; Rees 2005; Kennedy et al. 2008; Guinot et al. 2013).

Twenty years later, in a chapter on shark and ray faunas of the Gault Clay, Ward (2010) re-opened the taxonomic debate by synonymising all three species of Synechodus, relegating $S$. tenuis and $S$. nitidus into synonymy with S. dubrisiensis. According to Ward (2010: pl. 52, figs 5-8), all different morphotypes observed to that date resulted from intraspecific variations. To support his taxonomic act, he referred to the type specimens of both $S$. dubrisiensis (NHMUK PV OR 36908) and S. nitidus (NHMUK PV $P$ 1295). In these, Ward observed both 'dubrisiensis' and 'nitidus' like teeth, and in the latter, even 'tenuis' ones. According to Ward, the latter two are also present in the upper jaws of the 'hyoid arch specimen' (NHMUK PV OR 41675). Unfortunately, illustrations or descriptions to support his claim are lacking, neither did he address the nature of intraspecific variations observed in the type specimens, leaving heterodonty patterns in $S$. dubrisiensis unresolved. However, Adolfssen \& Ward (2015: 316) stated that anterior and presumed lower teeth displayed less folding, referring to monognathic and dignathic heterodonty, respectively, which contradicts with our observations made in the 'hyoid arch specimen' (NHMUK PV OR 41675; see appendix 1) that a lower anterior tooth possesses well-developed folds on the labial surface.

Recently, Siversson \& Machalski (2017) have challenged these observations as well. In contrast to Ward (2010), they did not find teeth of the 'nitidus' morphotype in NHMUK PV OR 41675, not in the upper, nor in the lower jaws. Subsequently, they rejected the synonymy proposed by Ward (2010), but also that of Batchelor \& Ward (1990). Their conflicting observations might be the result of different interpretations of what the 'nitidus' morphotype would look like exactly. Not the holotype (NHMUK PV P 1295), but a single lateral tooth (whereabouts unknown), broader than tall, with strong vertical ridges on its labial surface, a slender principal cusp that slightly bends towards the commissure and is flanked by pairs of well-individualised cusplets, illustrated by Ward (2010: pl. 52, fig. 6), was said to be indicative of the 'nitidus' morphotype. However, such teeth are, at least in our view, identical to those seen in the holotype of $S$. dubrisiensis; not in $S$. nitidus which shows a different tooth morphology (see Appendix 1).

The associated tooth set of the 'Boulonnais specimen' (IRScNB P.9895) includes several isolated teeth from anterior, lateral and posterior files. In addition to a strong monognathic heterodonty, it shows a unique combination of tooth morphologies not illustrated in a single individual to date.
Not only does the dentition of the 'Boulonnais specimen' combine weakly ornamented anterior teeth and strongly reticulated latero-posterior ones (see also associated tooth set NHMUK PV P 66223, 66225, 66226; Ward 2010: pl. 52, figs $5,7,8)$, it also includes larger antero-lateral ones that are similar to those seen in the holotype of $S$. dubrisiensis (NHMUK PV OR 36908) and other specimens with analogous teeth such as the 'Booth' (BMB 008523) and the 'braincase specimen' (NHMUK PV P 6315).

Consequently, it appears that weak/unornamented anterior teeth are no longer diagnostic of $S$. nitidus but are also present in $S$. dubrisiensis. This observation favours their synonymy, as suggested by Ward (2010), but does not necessarily reject the possibility that more than one Albian Synechodus species occurred in the Anglo-Paris Basin. The difference in ornamention between anterior and lateroposterior teeth might be characteristic of more than just one taxon (see e.g. Cappetta 2012: fig. 306) and species differentiation might be much more complex.

Despite the high quality of preservation of the type specimens of both $S$. dubrisiensis and $S$. nitidus, and many other exceptionally well-preserved material, the heterodonty of Albian Synechodus is yet not completely understood. Awaiting a thorough revision of Cretaceous Synechodus, especially those occurring in the Albian, the 'Boulonnais specimen' is left in open nomenclature and referred to as Synechodus sp.

\section{Acknowledgements}

We wish to express our gratitude to Luc De Coninck (Nieuwkerken-Waas) for donating the 'Boulonnais specimen' to the IRScNB (Brussels) and making it available for scientific study and description; Louis De Putter (Axel) and Pieter De Coninck (Nieuwkerken-Waas) for their help in salvaging the specimen in situ; the late Maria Hovestadt-Euler (Terneuzen) for preparing the specimen and processing of the clay; Barry W. M. van Bakel (Uden) for macro-photography; Alexander O. Ivanov and Sergey Nilov (Institute of Earth Sciences, St Petersburg) for micro CT scanning; Annelise Folie, Julien Cillis, Jacques Herman (retired), Ulysse Lefèvre and Patrick Semal (all Royal Belgian Institute of Natural Sciences, Brussels) for providing SEM photography and CT scanning; Pieter J. De Schutter (Opwijk) for logistic support; John A. Cooper (Booth Museum of Natural History, Brighton) for information on a specimen under his care; Mikael Siversson (Western Australian Museum, Welshpool) for discussions on palaeospinacid dentition; Christopher J. Duffin (Natural History Museum, London) for his advice on root terminology; Stefanie Klug (University of Manchester) for providing items of literature; Sébastien Enault (Montpellier University) for French translations; John W. M. Jagt (Natuurhistorisch Museum Maastricht) for critically reading of an earlier version of the typescript and suggesting linguistic improvements; Jürgen Kriwet (University of Vienna) and an anonymous reviewer for their constructive comments. 


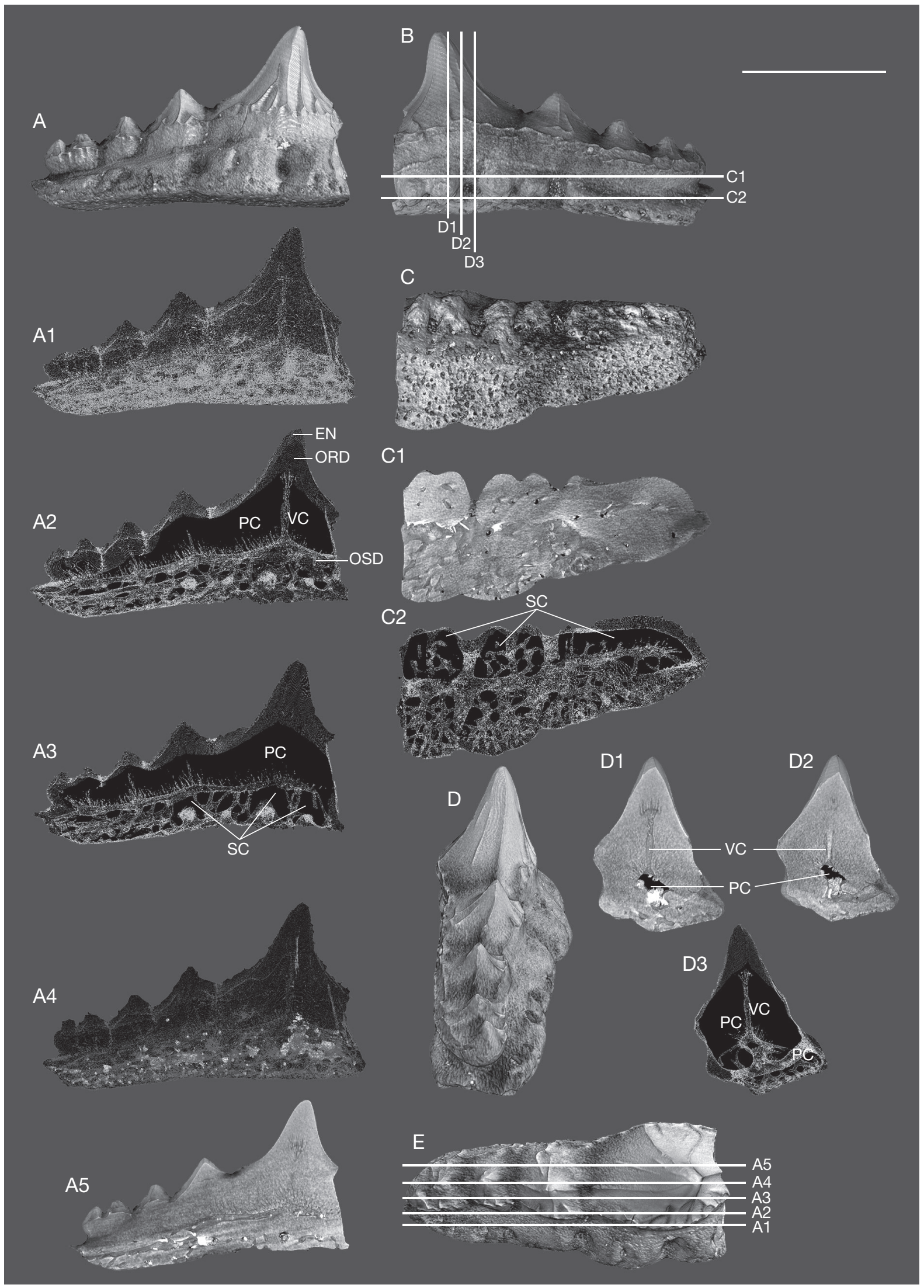

FIG. 7. - Micro CT scan of an isolated tooth of Synechodus sp. (IRScNB P.9895), Saint-Pô Formation (Albian, Lower Cretaceous), Boulonnais beach between Escalles and Strouanne (northern France): A, lingual; B, labial; C, basal; D, lateral and E, occlusal views; 3D volume renderings with sagittal (A1-A5), transverse (C1-C2) and frontal (D1-D3) sections showing tooth vascularisation and histology as follows: EN, enameloid; PC, pulp cavity; ORD, orthodentine; OSD, osteodentine; SC, secondary cavities; VC, vascular canaliculi. Scale bar: $1 \mathrm{~mm}$. 


\section{REFERENCES}

Adnet S., Cappetta H. \& Mertiniene R. 2008. - Re-evaluation of squaloid shark records from the Albian and Cenomanian of Lithuania. Cretaceous Research 29: 711-722. https://doi. org/10.1016/j.cretres.2008.01.014

AdolfSSEN J. S. \& Ward D. J. 2015. - Neoselachians from the Danian (early Paleocene) of Denmark. Acta Palaeontologica Polonica 60 (2): 313-338. https://doi.org/10.4202/app.2012.0123

AMÉDRO F. 2009. — La baie de Wissant et la carrière de Lottinghen (Pas-de-Calais) : deux coupes de référence dans l'Albien du Nord de la France. Annales de la Société géologique du Nord (2) 16: 1-14. http://hdl.handle.net/1908/2915

ARCHIAC A. D' 1838. - Observations sur le groupe moyen de la formation Crétacée. Mémoires de la Société géologique de France 3 (1): 261-311. https://biodiversitylibrary.org/page/42370561

BARrois C. 1874. - Catalogue des poissons fossiles du terrain crétacé du Nord de la France. Bulletin scientifique, historique et littéraire du Département du Nord et des Pays voisins 6: 101-110, 130-136. http://hdl.handle.net/1908/2071

BATCHELOR T. J. \& WARD D. J. 1990. — Fish remains from a temporary exposure of Hythe Beds (Aptian-Lower Cretaceous) near Godstone, Surrey. Mesozoic Research 2 (4): 181-203.

BidDlE J. P. 1993. — Les elasmobranches de l'Albien inférieur et moyen (Crétacé inférieur) de la Marne et de la Haute-Marne (France), in HERMAN J. \& VAN WAES H. (eds), Elasmobranches et stratigraphie. Service géologique de Belgique, Professional Paper 6 (264): 191-240.

BONAPARTE C. L. J. L. 1838. - Selachorum tabula analytica. Nuovi Annali delle Scienze Naturali 2: 195-214. https://biodiversitylibrary.org/page/9327388

CAPpeTTA H. 1977. - Sélaciens nouveaux de l'Albien supérieur de Wissant (Pas-de-Calais). Geobios 10 (6): 967-973. https://doi. org/10.1016/S0016-6995(77)80085-5

CAPPETTA H. 1987. - Chondrichthyes II, Mesozoic and Cenozoic Elasmobranchii, in SCHULTZE H.-P. (ed.), Handbook of Paleoichthyology. Volume 3B. Gustav Fischer, Stuttgart, 193 p.

CAPPETTA H. 2010. - Les requins et les raies (chondrichthyens), in Colleté C. (ed.), Stratotype Albien. Muséum national d'Histoire naturelle, Paris: 231-235.

CappetTA H. 2012. - Chondrichthyes, Mesozoic and Cenozoic Elasmobranchii: teeth, in SCHULTZE H.-P. (ed.), Handbook of Paleoichthyology. Volume 3E. Friedrich Pfeil, München, 512 p.

Compagno L. J. V. 1977. — Phyletic relationships of living sharks and rays. American Zoologist 17: 303-322. http://www.jstor.org/ stable/3882097

DALINKEVIČIUS J. A. 1935. - On the fossil fishes of the Lithuanian Chalk. I. Selachii. Mémoires de la Faculté des Sciences de l'Université de Vytautas le Grand 9: 245-305.

DEAN B. 1909. - Studies on fossil fishes (sharks, chimaeroids, and arthrodires). A well-preserved specimen of the Liassic shark, Palaeospinax priscus. Memoirs of the American Museum of Natural History 9 (5): 254-257. http://hdl.handle.net/2246/57

Destombes J.-P. \& Destombes P. 1937. - Note sur le Gault de Wissant. Annales de la Société géologique du Nord 62: 98-113. https://gallica.bnf.fr/ark:/12148/bpt6k5723877g/f118.item

DufFin C. J. \& WARD D. J. 1993. - The Early Jurassic palaeospinacid sharks of Lyme Regis, southern England, in HERMAN J. \& VAN WAES H. (eds), Elasmobranches et stratigraphie. Service géologique de Belgique, Professional Paper 6 (264): 53-102.

GUINOT G. 2011. - Selachians from the Late Cretaceous of the Anglo-Paris Basin: Systematics, Diversity and Palaeoecology. PhD thesis, Birkbeck College, University of Londen and University of Montpellier, 503 p. (unpublished).

Guinot G., Underwood C. J., CAPpetta H. \& Ward D. J. 2013. - Sharks (Elasmobranchii: Euselachii) from the Late Cretaceous of France and the UK. Journal of Systematic Palaeontology 11(6): 589-671. https://doi.org/10.1080/14772019.2013.767286
HASSE C. 1879. - Das natürliche System der Elasmobranchier auf Grundlage des Baues und der Entwicklung ihrer Wirbelsäule. Eine morphologische und paläontologische Studie. Gustav Fischer, Jena, 76 p. https://doi.org/10.5962/bhl.title.8431

Herman J. 1977. - Les sélaciens des terrains néocrétacés \& paléocènes de Belgique $\&$ des contrées limitrophes, éléments d'une biostratigraphie intercontinentale. Mémoires explicatives des Cartes géologiques et minières de la Belgique 15: 1-401.

HuXLEY T. H. 1880. - On the application of the laws of evolution to the arrangement of the Vertebrata, and more particularly of the Mammalia. Proceedings of the Scientific Meetings of the Zoological Society of London 1880: 649-662. https://biodiversitylibrary.org/ page/28522869

KENNEDY W. J., KInG C. \& WARD D. J. 2008. — The upper Albian and lower Cenomanian succession at Kolbay, eastern Mangyshlak (southwest Kazakhstan). Bulletin de l'Institut royal des Sciences naturelles de Belgique, Sciences de la Terre 78: 117-147.

KLUG S. 2010. - Monophyly, phylogeny and systematic position of the + Synechodontiformes (Chondrichthyes, Neoselachii). Zoologica Scripta 39 (1): 37-49. https://doi.org/10.1111/j.14636409.2009.00399.x

KLUG S. \& KRIWET J. 2006. - Anatomy and systematics of the Early Jurassic neoselachian shark Synechodus smithwoodwardi (Fraas, 1896) from southern Germany. Neues Jahrbuch für Geologie und Paläontologie, Monatshefte 2006 (4): 193-211.

KLUG S. \& KRIWET J. 2008. - A new basal galeomorph shark (Synechodontiformes, Neoselachii) from the Early Jurassic of Europe. Naturwissenschaften 95: 443-448. https://doi.org/10.1007/ s00114-007-0341-0

LERICHE M. 1906. — Contribution à l'étude des poissons fossiles du Nord de la France et des régions voisines. Mémoires de la Société géologique du Nord 5: 1-430. http://hdl.handle.net/1908/2084

MACKIE S. J. 1863. - On a new species of Hybodus from the Lower Chalk. The Geologist 6: 241-246. https://doi.org/10.1017/ S1359465600001209

MAISEY J. G. 1985. — Cranial morphology of the fossil elasmobranch Synechodus dubrisiensis. American Museum Novitates 2804: 1-28. http://hdl.handle.net/2246/5280

Maisey J. G., NaYlor G. J. P. \& Ward D. J. 2004. - Mesozoic elasmobranchs, neoselachian phylogeny and the rise of modern elasmobranch diversity, in ArRATIA G. \&Tintori A. (eds), Mesozoic Fishes 3, Systematics, Paleoenvironments and Biodiversity. Friedrich Pfeil, München: 17-56.

RANDELl R. \& BALMBRA C. 2018. - British Chalk Fossils. Retreived from http://www.chalk.discoveringfossils.co.uk (June 28, 2018).

REES J. 2005. - Neoselachian shark and ray teeth from the Valanginian, Lower Cretaceous, of Wąwał, Central Poland. Palaeontology 48 (2): 209-221. https://doi.org/10.1111/j.1475-4983.2005.00441.x

REgAN T. C. 1906. - A classification of the selachian fishes. Proceedings of the General Meetings for Scientific Business of the Zoological Society of London 1906: 722-758.

REIF W.-E. 1973. - Ontogenese des Hautskelettes von Heterodontus falcifer (Selachii) aus dem Untertithon. Vergleichende Morphologie der Hautzähnchen der Haie. Stuttgarter Beiträge zur Naturkunde B7: 1-16.

REIF W.-E. 1985. - Squamation and ecology of sharks. Courier Forschungsinstitut Senckenberg 78: 1-101.

ROBASZYNSKI F. \& AMÉDRO F. 1986. - The Cretaceous of the Boulonnais (France) and a comparison with the Cretaceous of Kent (United Kingdom). Proceedings of the Geologists' Association 97 (2): 171-208. https://doi.org/10.1016/S0016-7878(86)80067-0

SAUVAGE E. 1868. - Poissons fossiles des formations secondaires du Boulonnais. Mémoires de la Société académique de l'Arrondissement de Boulogne-sur-Mer 1866-1867: 53-152. https://gallica.bnf.fr/ ark:/12148/bpt6k54975025/f53.item

Siversson M., CoOK T. D., Cederström P. \& Ryan H. E. 2016. Early Campanian (Late Cretaceous) squatiniform and synechodontiform selachians from the Åsen locality, Kristianstad Basin, 
Sweden, in Kear B. P., Lindgren J., Hurum J. H., Milàn J. \& VajdA V. (eds), Mesozoic Biotas of Scandinavia and its Arctic Territories. Geological Society, London, Special Publications 434: 251-275. https://doi.org/10.1144/SP434.9

SiVERSSON M. \& MACHALSKI M. 2017. — Late late Albian (Early Cretaceous) shark teeth from Annopol, Poland. Alcheringa 41: 433-463. https://doi.org/10.1080/03115518.2017.1282981

Smith M. M., Underwood C., Clark B., Kriwet J. \& Johanson Z. 2018. - Development and evolution of tooth renewal in neoselachian sharks as a model for transformation in chondrichthyan dentitions. Journal of Anatomy 232 : 891-907. https://doi. org/10.1111/joa.12796

UnderWood C. J. \& Mitchell S. F. 1999. - Albian and Cenomanian selachian assemblages from north-east England. Special Papers in Palaeontology 60: 9-56.

WARD D. J. 2010. — Shark and rays, in YounG J. R., GALE A. S. Knight R. I. \& SMith A. B. (eds), Field Guide to Fossils 12: Fossils of the Gault Clay. The Palaeontological Association, London: 275-299.

WOODWARD A. S. 1886a. - On the relations of the mandibular and hyoid arches in a Cretaceous shark (Hybodus dubrisiensis,
Mackie). Proceedings of the Scientific Meetings of the Zoological Society of London 1886: 218-224. https://biodiversitylibrary. org/page/30829432

WOODWARD A. S. 1886b. - On the relations of the mandibular and hyoid arches in a Cretaceous shark (Hybodus dubrisiensis, Mackie). The Geological Magazine (3) 3 (6): 285-286.

WOODWARD A. S. 1888. - On the Cretaceous selachian genus Synechodus. The Geological Magazine (3) 5 (11): 496-499. https:// doi.org/10.1017/S0016756800182767

WoODWARD A. S. 1889. - Catalogue of the Fossil Fishes in the British Museum (Natural History). Part I. Elasmobranchii. Printed by order of the Trustees, London, 474 p. https://biodiversitylibrary. org/page/51766771

WOODWARD A. S. 1898. - Outlines of vertebrate palaeontology for students of zoology, in SHIPLEY E. (ed.), Cambridge Natural Science Manuals, Biological series. University Press, Cambridge, 470 p. https://doi.org/10.5962/bhl.title.33747

WoOdWard A. S. 1902-1912. — The Fossil Fishes of the English Chalk. Monograph of the Palaeontographical Society London, 264 p.

Submitted on 9 February 2018;

accepted on 7 September 2018;

published on 20 December 2018. 


\section{APPENDIX}

APPENDIX 1. - Review of the taxonomic history of Synechodus dubrisiensis (Mackie, 1863), S. nitidus Woodward, 1911 and S. tenuis Woodward, 1889. For NHMUK and BMB photographs see http://www.chalk.discoveringfossils.co.uk (June 28, 2018).

1863

Description of Hybodus dubrisiensis

(NHMUK PV OR 36908, the holotype)

A well-preserved set of articulated jaws (mandibular arch) that includes at least 25 teeth, originating from the Zig Zag Chalk Formation ('Grey Chalk', Holaster subglobosus zone, Cenomanian) of Dover (England) was first described by Mackie (1863: pl. 13, figs 1-2) as a new species, Hybodus dubrisiensis.

Because of its relatively small size and lesser degree of calcification, the specimen was considered to represent a juvenile (Woodward 1886a, 1911). Mackie (1863) distinguished anterior, lateral and posterior teeth but did not assign these teeth to upper and/or lower jaws, although both uppers and lowers are present according to Ward (2010: 281), an opinion followed here. The height of the principal cusp equals the width of the tooth base in anterior teeth, but decreases in lateral and even more so in posterior files, which suggests at least a gradient monognathic heterodonty in the holotype. No indications of ornamentation were given in the original account. Evidently, Mackie was set to compare his new species with Hybodus, and no other genera. Additional information and illustrations of the holotype were subsequently provided by Woodward (1911: pl. 45, fig. 6-6a), including details of a single asymmetrically shaped lateral tooth showing strong basal vertical ridges on the labial face, having a slender principal cusp bending towards the commissure. The tooth possesses three distal $v$ s. two mesial cusplets that are well individualised. In labial view, its mesial cutting edge is clearly convex and the root base is slightly arched. Based on the original drawing of the holotype, as well as new photographic evidence (courtesy of NHMUK), this tooth is here interpreted to have originated from an antero-lateral file in the right half of the lower jaw. According to Woodward (1911:218) this particular tooth was similar to those seen in the fourth row in the 'Booth specimen' (BMB 008523, see below). Based on the same photographic evidence, the right side of the holotype also yields a group of similar teeth, but with a more upright principal cusp, and with a mesial cutting edge that is concave to slightly sigmoid in the same labial view, and with the basal edge of the root more arched. These are interpreted here to have stemmed from the opposite jaws, as such analogous teeth have been reported from the upper jaws of the 'braincase specimen' (NHMUK PV P 6315, see below), indicating at least a weak dignathic heterodonty as well.

\section{6}

Two additional skeletal specimens, identified as $\mathrm{H}$. dubrisiensis (NHMUK PV OR 41675, the 'hyoid arch specimen' and NHMUK PV OR 49032, the 'pelvic girdle specimen')

Twenty-three years after the original description of $H$. dubrisiensis, Woodward (1886a, b) recorded two additional specimens from the English Chalk (Cenomanian) at Kent. The first of these is another exceptional set of articulated jaws, this time from a larger individual, with the hyoid arch (hyomandibula and cerathohyal) preserved as well (NHMUK PV OR 41675; for a photograph see Maisey et al. 2004: fig. 14); the second comprising the anterior portion of a skeleton that includes a small part of the braincase, a series of vertebrae, the pectoral girdle and several dermal denticles (NHMUK PV OR 49032; illustrated later by Woodward [1911: pl. 46, fig. 2]). In the latter specimen, no teeth were reported, in contrast to the 'hyoid arch specimen' that includes many teeth, particulary from the right halves of the jaws. According to Woodward (1886a: 220), they are "undistinguishable [sic] in general character" from those of the holotype, and thus identified as $H$. dubrisiensis. Focusing on hyoid arch morphology, he briefly discussed teeth and heterodonty, adding - just on this specific topic - little to the original account by Mackie (1863), except for the illustration of an anterior and posterior tooth (Woodward 1886a: pl. 20, fig. 3a, 3b respectively). The first symmetrical, robust tooth, illustrated in labial view, lacks the root (at least in the figure; it may perhaps be still embedded in chalk matrix). The crown is slightly taller than broad, with three pairs of low cusplets that are hardly individualised. Its base is slightly arched. It is not clear if a very weak ornamention is present near the basal edge of the crown, but vertical folds are definitely not present in this specific illustration. Although these teeth have not been attributed either to the upper or lower jaws in the original account, the largest one was presumed to have stemmed from an upper anterior file (see Woodward 1888: 497, footnote 1, clearly referring to fig. 3a of his original account). This opinion was followed not only for the anterior one, but also for the posterior one (compare Woodward 1886a: fig. 3b) by Ward (2010: 281 "apparantly both in the upper jaws").

An anterior and posterior tooth from the same 'hyoid arch specimen' was illustrated twice again by Woodward (1889, 1911) and superficially resemble the ones illustrated in the original account. However, the base of the anterior tooth illustrated by Woodward (1889: pl. 11, fig. 17) is slightly more arched, and its labial face now shows strong vertical folds, up to half the crown's height. These two features are even more pronounced in Woodward (1911: pl. 45, fig. 7b). Moreover, the height of the principal cusp is reduced compared to the specimen figured in the original description. Having access to new photographic evidence (courtesy of Charlie Underwood and NHMUK), Siversson et al. (2016) attributed the tooth figured by Woodward (1911) to the lower jaws, an opinion followed here. This sheds new light on the dentition of the specimen, because Woodward failed to give such indications, not in his 1889 paper, nor in the one published in 1911 .

These observations imply that at least two subsequent illustrations by Woodward (1886a, 1911) in fact represent different anterior teeth, i.e., upper vs lower, respectively. Both 
teeth are symmetrical and robust, but, in lowers, the principal cusp is less elongated, has stronger labial folds, and has a crown base that is much more arched, reflecting a significant dignathic heterodonty other than the one already observed in the holotype (see above).

However, this contradicts another observation by Siversson et al. (2016: 264) of upper anterior teeth in the same 'hyoid arch specimen' (NHMUK PV OR 41675), but also yet another specimen (NHMUK PV P 6315; for discussion, see below) that are "asymmetrical with (...) relatively large widely spaced cusplets and a moderate labial overhang of the root". Moreover, an upper anterior tooth (also NHMUK PV OR 41675) is said to be strongly folded on its labial face (see Siversson \& Machalski 2017).

These new observations would imply that Woodward was mistaken in attributing the tooth illustrated in 1886 to the upper jaws, and/or in not showing the ornamentation. In this case, all three illustrations (i.e., in Woodward 1886a, 1889,1911 ) would rather reflect the same individual tooth (or at least jaw file, i.e., lower, not upper) which became more detailed in subsequent versions.

Irrespective of these contradicting conclusions, it is clear that antero-lateral teeth of the 'hyoid arch specimen' at least differ from those of the holotype (but also other specimens, including e.g. BMB 008523, NHMUK PV OR 47287 and NHMUK PV P 6315, see below) in having broad-based principal cusps that are much more robust, and lateral cusplets that are less individualised. These mutual differences were clearly depicted by Woodward (1889: pl. 11, figs 17, 20 vs figs 15, 19).

\section{8}

Erection of the genus Synechodus and discovery of a complete dental set in its natural position and identified as $\mathrm{H}$. dubrisiensis (BMB 008523, the 'Booth specimen')

Two years later, Woodward (1888) erected a new genus, Synechodus, to accommodate $H$. dubrisiensis, and recorded a set of about 140 complete teeth (BMB 008523) from the 'Grey Chalk' (Cenomanian) of Sussex (England). These teeth are preserved in their natural position, and represent a complete dentition of one of the jaws (both left and right halves together), but none of the cartilage was preserved (for reillustrations of the 'Booth specimen', see e.g. Woodward 1889: 326; 1898 : 47; 1911: pl. 46, fig. 1; Guinot 2011: appendix 2; Cappetta 2012: 320 , fig. 305 , not fig. 310 - the text and accompanying illustration is confusing and might suggest that the 'Booth specimen' represents the holotype of $S$. dubrisiensis, which is erroneous; Smith et al. 2018: fig. 10A-I). Contrary to previous accounts, Woodward (1888) now also focused on the ornamentation of the teeth. In all teeth, the principal cusp shows clear vertical folds and the tooth bases are reticulated. As seen in the holotype, lateral teeth have slender principal cusps (but less arched), flanked by numerous pairs of lateral cusplets that are well individualised.

Woodward (1888) counted eleven dental files in both halves of the jaws. In each half, teeth of the first file are extremely small compared to the other antero-lateral tooth files in the same jaw. Woodward had not observed such parasymphysal teeth in previous material of $S$. dubrisiensis. Moreover, an anterior tooth from the 'hyoid arch specimen' (NHMUK PV OR 41675), presumed by Woodward (1888) to have originated from the upper jaws (but not necessarily by Siversson $e t$ al. 2016; for discussion, see above), was much more robust, and had more pairs of lateral cusplets than those observed in the 'Booth specimen'. Nevertheless, Woodward was convinced that both specimens represented the same species. He suggested that this difference resulted from dignathic heterodonty, but did not rule out sexual dimorphism either. Consequently, Woodward considered specimen BMB 008523 to represent the dentition of a lower jaw (Meckel's cartilage), an opinion followed by Maisey (1985) and Duffin \& Ward (1993). This also corresponds with a subsequent observation by Woodward (1911: 218) that teeth of the fourth row of the 'Booth specimen' were similar to a lower antero-lateral tooth preserved in its natural position in the lower jaws of the holotype (see above; Woodward [1911: pl. 45, fig. 6a]). Other researchers who referred to this specimen (e.g., Ward 2010; Cappetta 2012; Guinot et al. 2013) neither ascribed to nor discussed Woodward's conclusion. In contrast, Siversson et al. (2016) referred to this specimen when discussing the upper dentition and thus rejected Woodward's interpretation (M. Siversson, pers. comm., September 2017), as was first suggested by Guinot (2011). This is evident, as the argumentation by Woodward and Siversson et al. (2016) started differently, that is in the presumed origin (i.e., upper or lower) of comparative anterior teeth figured so far from the 'hyoid arch specimen' (NHMUK PV OR 41675; see Woodward 1886a, 1889, 1911 and discussion above).

\section{9}

Catalogue of fossil fishes in the British Museum, listing new material of $S$. dubrisiensis and describing a new species, Synechodus tenuis (NHMUK PV OR 9297, holotype) One year later, Woodward (1889) presented the first part (Elasmobranchii) of his catalogue of fossil fishes in the British Museum (Natural History), in which he listed all S. dubrisiensis material. In addition to the London material discussed above (i.e., 'hyoid arch' and the 'pectoral girdle specimen'), new material was added and, in part, illustrated (i.e., NHMUK PV OR 47287; Woodward 1889: pl. 11, figs 18, 19). The new material also included the remains of a large head (NHMUK PV P 1295, not illustrated in the original account), with jaws, several teeth and dermal denticles preserved. Woodward noted that its teeth differed from all other $S$. dubrisiensis material by the smoothness of the principal cusp. Nevertheless, he considered it to be the same species, although stressed the large size of the head/fish and thus possible ontogenetic heterodonty. Yet, twenty two years later, Woodward (1911) would describe this particular specimen as a new species, $S$. nitidus (see below).

However, the complex and unresolved heterodonty observed in S. dubrisiensis so far (monognathic, dignathic and possible ontogenetic or sexual dimorphism), did not prevent Woodward (1889) from erecting a new species of Synechodus, i.e., S. tenuis. This species is based on four loose teeth (NHMUK PV OR 9297 - 3 teeth, all incomplete, and NHMUK PV 
OR 39218 - 1 tooth), of which only the holotype (NHMUK PV OR 9297, in part) was illustrated (Woodward 1889: pl. 11, fig. 21). It originated from the Lower Greensand (Aptian-lower Albian) of Maidstone (England) and is from an anterior tooth file. Compared to the type species, teeth of $S$. tenuis have a principal cusp that is more slender, with less conspicuous folds confined to the basal portion of the crown only and much more arched crown bases.

In view of the poor quality of the type material, Siversson et al. (2016) have recently considered $S$. tenuis to be a nomen dubium and in need of revision (see also Siversson \& Machalski 2017), an opinion followed here.

\section{1}

Fossil fishes of the English Chalk, reviewing previous accounts and describing Synechodus nitidus (NHMUK PV P 1295, holotype)

In his monograph entitled Fossil fishes of the English Chalk, Woodward (1902-1912, pages and plates related to Synechodus all published in 1911) presented a review of his observations and research conducted to that moment. Several specimens of S. dubrisiensis were reillustrated, and a drawing of the 'pectoral girdle specimen' (NHMUK PV OR 49032) was presented for the first time (Woodward 1911: pl. 46, fig. 2-2a). The same applies for specimen NHMUK PV P 1295 (Woodward 1911: pl. 46, figs 3-4), but Woodward no longer considered it to represent a large $S$. dubrisiensis (see Woodward 1889: 329), but assigned it to a new species of Synechodus, i.e., S. nitidus.
In addition to its larger size, $S$. nitidus differs from the type species by its anterior teeth that are smooth, with lateral cusplets that are more slender. Antero-lateral tooth files show fine vertical folds at the base of the crown. Posterior teeth have sharply pointed cusps, also marked with such vertical folds, but no reticulations. Unfortunately, a comparison with $S$. tenuis was not given. The latter species was not listed by Woodward (1902-1912), because it did not occur in the English Chalk, but originated from the underlying Lower Greensand (Aptian-Albian).

\section{5}

Description of yet another unreported specimen including a well-preserved neurocranium (NHMUK PV P 6315, the 'braincase specimen')

Since Woodward (1886a, 1888, 1889, 1902-1912), only a single new and important skeletal specimen has been recorded from the English Chalk, by Maisey (1985); this was identified as $S$. dubrisiensis. This specimen (NHMUK PV P 6315) has a three-dimensionally preserved braincase, as well as both upper and lower jaws, including numerous teeth. Based on new photographic evidence (courtesy of NHMUK), lateral upper teeth are asymmetrical, have a slender principal cusp and several pairs of well-individualised cusplets. In labial view, the crown shows basal vertical folds. The mesial cutting edge of the principal cusp is concave to slightly sigmoid and the root base arched. Such tooth morphology is also present in the holotype (see above). 